\title{
PEMANFAATAN KADAL (Eutropis multifasciata) SEBAGAI OBAT ALERGI GATAL OLEH MASYARAKAT SUMBER, KABUPATEN CIREBON
}

\author{
Siti Rahma \\ Jurusan Tadris Biologi, IAIN Syekh Nurjati Cirebon \\ Email: sitirahma431@gmail.com
}

\begin{abstract}
ABSTRAK: Kadal merupakan hewan bertulang belakang (vertebrata) yang termasuk ke dalam kelompok Reptil. Reptil merupakan hewan ektotermal yang emmerlukan sumber panas dari lingkungan untuk melakukan suatu kegiatan metabolismenya. Kadal (Eutropis multifasciata) dimanfaatkan dalam bidang farmasi yaitu sebagai obat alergi gatal. Tujuan penelitian ini yaitu untuk mengetahui pemanfaatan kadal sebagai obat alergi gatal dan mengetahui hukum memakan kadal dalam agama Islam. Metode yang digunakan yaitu wawancara terhadap beberapa narasumber dan observasi mengenai cara konsumsi kadal. Berdasarkan hasil penelitian, kadal memiliki kandungan antimikroba yang dapat melawan bakteri dan jamur patogen. Kesimpulannya yaitu kadal dapat dimanfaatkan untuk mengobati penyakit kulit dan diperbolehkan dikonsumsi jika termasuk jenis dhab (kadal herbivora).
\end{abstract}

Kata Kunci: Eutropis multifasciata, Gatal, Antimikroba

ABSTRACT: Lizards are vertebrates that belong to the Reptile group. Reptiles are ectothermal animals that require a heat source from the environment to carry out their metabolic activities. Lizards (Eutropic multifasciata) are used in the pharmaceutical field as an itchy allergy medicine. The purpose of this study is to find out the use of lizards as an itchy allergy medicine and to know the law of eating lizards in Islam. The method used is interviewing several speakers and observations on how to consume lizards. Based on the results of the study, lizards have antimicrobial content that can fight pathogenic bacteria and fungi. The conclusion is that lizards can be used to treat skin diseases and allowed to be consumed if they belong to the type of dhab (herbivorous lizards).

Keywords: Eutropis multifasciata, Itching, Antimicrobial

\section{PENDAHULUAN}

Menurut Anderson dkk. (2011), etnozoologi merupakan suatu ilmu yang mengkaji mengenai pengetahuan lokal dan juga hubungan antara manusia, hewan serta lingkungan di sekitarnya. Kehidupan manusia tentunya tidak terlepas dari adanya pemanfaatan sumber daya hayati dalam memenuhi kebutuhan sehari-hari. Sumber daya hayati tersebut mencangkup hewan dan juga tumbuhan. Menurut Lesmana dkk. (2018), pengobatan tradisional sudah dilaksanakan dari zaman dahulu hingga sekarang. Biasanya obat tradisional diperoleh dari tanaman hidup yang berada di lingkungan sekitar rumah ataupun di hutan. Tetapi, obat tradisional juga dapat diperoleh dari hewan-hewan yang diolah dengan baik. Obat tradisional merupakan suatu bahan atau ramuan yang berasal dari tumbuh-tumbuhan, hewan, dan lainnya 
yang digunakan dalam pengobatan alami tanpa bahan kimia berdasarkan suatu pengalaman.

Pada zaman dahulu, masyarakat Sumber mempercayai bahwa mengonsumsi kadal dapat meringankan gatal-gatal. Kadal yang biasa digunakan adalah kadal kebun (Eutropis multifasciata). Biasanya kadal dikonsumsi dengan cara dibuang bagian kulitnya, dibuang bagian organ dalam kadal dan digoreng hingga matang. Kadal biasanya sulit untuk ditangkap, oleh karena itu orang yang perlu kadal dapat membeli di pengepul atau orang yang biasa mencari kadal.

Pada masa kini, masyarakat sudah jarang mengonsumsi kadal untuk obat gatal. Masyarakat sudah terbiasa dengan obat-obat kimia yang dijual di apotek. Sehingga, hanya beberapa orang saja yang sesekali masih mengonsumsi kadal untuk meringankan gatal-gatal. Selain itu, generasi muda juga sudah jarang yang mengetahui tentang pemanfaatkan kadal sebagai obat gatal, sehingga kepercayaan atau tradisi zaman dahulu sudah tidak berkembang. Kadal sendiri selain dapat meringkankan gatal-gatal, kadal juga dapat mengobati penyakit ginjal dan meredakan asma. (Krisyanto dkk., 2019).

Menurut Eprilurahman dkk. (2018), kadal termasuk ke dalam kelompok Reptil. Reptil merupakan hewan ekotermal, yaitu memerlukan sumber panas dari lingkungan untuk melakukan suatu kegiatan metabolismenya. Oleh karena itu, Reptil sering sekali dijumpai sedang berjemur didaerah yang terbuka pada waktu pagi hari hingga siang hari untuk menyeimbangkan metabolisme tubuhnya tersebut. Reptil berjemur hingga mencapai suhu badan yang dibutuhkan dan selanjutnya akan bersembunyi atau melanjutkan aktivitasnya. Berdasarkan latar belakang tersebut, penulis merasa penasaran mengenai kadal yang dapat dimanfaatkan sebagai obat gatal. Oleh sebab itu, penulis akan melakukan suatu riset atau penelitian mandiri untuk mengetahui pemanfaatan kadal (Eutropis multifasciata) sebagai obat alergi gatal dan untuk mengetahui hukum mengonsumsi kadal di dalam agama Islam.

\section{METODE PENELITIAN}

Metode yang digunakan dalam penelitian ini adalah metode kualitatif yaitu berupa wawancara beserta observasi. Penulis melakukan wawancara dengan bertanya kepada beberapa narasumber mengenai beberapa hal yang berkaitan dengan pemanfaatan kadal sebagai obat alergi gatal. Narasumber tersebut adalah beberapa orang yang tinggal di Sumber, Cirebon, baik orang dewasa maupuan anak muda. Selanjutnya, observasi dilakukan dengan mengamati proses mematikan kadal hingga akhirnya dapat dikonsumsi dengan baik, lalu mencatatnya. Data yang telah diperoleh melalui wawancara dianalisis secara deskriptif dan dikaitkan dengan sumber lain yang relevan seperti jurnal nasional dan internasional.

Pengolahan kadal dilakukan dengan digoreng, alat yang digunakan yaitu wajan, kompor, gunting, jarum penusuk, piring, pisau dan pengaduk. Lalu, bahan yang digunakan yaitu kadal (Eutropis multifasciata), minyak goreng dan bumbu penyedap.

\section{HASIL DAN PEMBAHASAN}

Pemanfaatan Kadal sebagai Obat Alergi Gatal. 
Kadal (Eutropis multifasciata) merupakan salah satu hewan yang memiliki tulang belakang (Vertebrata) yang termasuk ke dalam kelas Reptil. Kadal memiliki panjang tubuh yang berukuran sekitar $5 \mathrm{~cm}$ hingga $32 \mathrm{~cm}$. Kadal memiliki caput yang terbentuk pipih meruncing bagian ujungnya, rahang atas dan juga bawah membatasi sisi mulut. Lalu, truncus atau badan ditutupi oleh kulit kering disertai dengan sisik-sisik zat tanduk, berbentuk bulat memanjang. Kemudian, sebelah belakang antara kaki dan ekor terdapat lubang kloaka. Cauda atau ekor kadal ini kukuh, bersisik, bentuknya bulat panjang meruncing ke ujungnya, dan mudah putus. Pada extremitas anterior terdapat 10 digiti (5 kanan dan 5 kiri), dan extremitas posterior terdapat 10 digiti (5 kanan dan 5 kiri), jadi total jumlah digiti yang dimiliki kadal yaitu 20 digiti. Pada bagian dorsal kadal berwarna cokelat tembaga, sedangkan pada bagian perut berwarna kekuningan dan bintik-bintik kuning. (Eprilurahman dkk., 2018)

Menurut Yuni dkk. (2018), kadal adalah hewan yang aktif mencari makanan atau mangsanya di waktu siang hari. Kadal termasuk ke dalam hewan ektoterm atau poikilotern, yang mana suhu tubuh kadal sangat dipengaruhi oleh suhu di lingkungan sekitarnya. Oleh karena itu, untuk beraktivitas dengan optimal kadal harus menjaga suhu tubuhnya pada kisaran suhu yang optimal. Salah satu upaya yang biasa dilakukan kadal adalah melakukan mekanisme termoregulasi. Termoregulasi merupakan suatu langkah atau mekanisme makhluk hidup yang dilakukan untuk mempertahankan suhu internalnya supaya dapat berada dalam kisaran suhu optimal. 2015)
Klasifikasi ilmiah kadal (Eutropis multifasciata):

$\begin{array}{ll}\text { Phylum } & \text { : Chordata } \\ \text { Subphylum } & \text { : Vertebrata } \\ \text { Class } & \text { : Reptilia } \\ \text { Ordo } & \text { : Squamata } \\ \text { Family } & \text { : Scincidae } \\ \text { Genus } & \text { : Eutropis } \\ \text { Species } & : \text { Eutropis multifasciata } \\ \text { Author } & : \text { Kuhl, 1820 }\end{array}$

Gambar 1. Kadal (Eiutropis multifasciata) (Sumber: Foto pribadi)

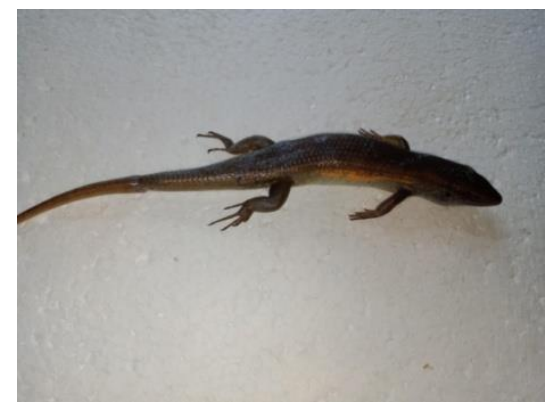

Kadal dapat hidup di berbagai habitat, seperti dipepohonan, diatas tanah, bahkan dapat hidup di dalam tanah. Kadal menyukai habitat di tempat yang lembab dan juga tempat yang memiliki banyak serasah, pepohonan dan juga semak-semak. Kadal merupakan salah satu hewan sebagai penyusun ekosistem dan bagian keanekaragaman hayati yang menempati kawasan hutan dan perkebunan. Kadal juga memegang peranan penting dalam rantai makanan dilingkungannya, keseimbangan alam dan juga bagi lingkungan manusia. Kadal dapat dijadikan sebagai indikator terhadap melimpahnya serangga yang ada di sekitar. Makanan utama kadal yaitu berbagai macam dari larva serangga dan juga serangga yang menjadi hama, sehingga kadal dapat menekan keberadaan serangga yang bersifat merugikan bagi manusia. (Rosadi dkk., 2017) 
Berdasarkan wawancara dan
observasi yang telah dilakukan
terhadap beberapa narasumber
mengenai pemanfaatan kadal sebagai
obat alergi gatal, maka didapatkan hasil
bahwa narasumber 1 mengatakan
bahwa zaman dulu beberapa orang Sumber mengonsumsi kadal untuk mengobati alergi gatal, tetapi zaman sekarng sudah jarang, karena sudah ada obat kimia untuk mengobati alergi gatal. Narasumber 1 pun tidak pernah mengonsumsi kadal. Lalu, Narasumber 2 mengatakan bahwa kadal dapat dimanfaatkan untuk meringankan gatal-gatal, cara mengonsumsinya yaitu dengan digoreng. Narasumber 2 pernah mengonsumsi kadal ketika gatal kambuh. Setelah makan kadal yang sudah digoreng, badan terasa hangat dan beberapa hari kemudian, gatalgatal sudah reda dan sembuh. Selanjutnya, beberapa narasumber lainnya seperti Ibu-Ibu yang sudah berumur mengetahui bahwa kadal dapat dimanfaatkan sebagai obat gatal. Tetapi narasumber lain seperti anak muda, tidak mengetahui hal tersebut.

Berdasarkan penelitian yang telah didapatkan, maka dapat dikatakan bahwa pada zaman dahulu masyarakat Sumber telah memanfaatkan kadal dalam bidang farmasi yaitu sebagai obat tradisional. Kadal tersebut dimanfaatkan oleh masyarakat Sumber untuk meringankan alergi gatal-gatal. Cara konsumsi kadal yang dilakukan masyarakat Sumber yaitu dengan cara dibuang bagian kulit dan organ-organ dalam kadal hingga bersih, sehingga tidak ada darah yang tersisa. Setelah itu, daging kadal digoreng hingga matang yang ditandai dengan warna kecokelatan pada daging kadal (Dilihat pada gambar 2).

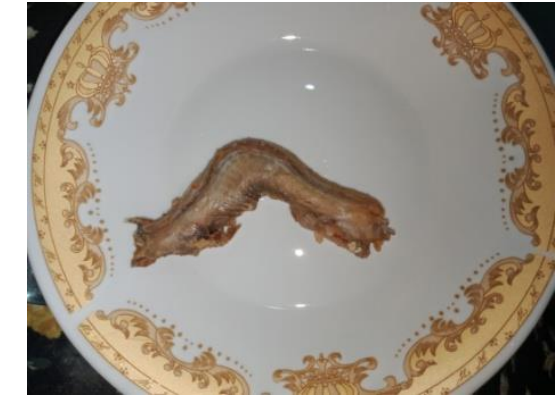

Gambar 2. Kadal yang sudah digoreng berwarna kecokelatam (Sumber: Foto pribadi)

Kadal yang digoreng hingga matang bertujuan agar tidak ada bakteri atau mikroba yang tertinggal pada daging kadal, sehingga baik dan aman untuk kesehatan. Menurut Walia dan Gusnita (2020), daging hewan yang diolah untuk dikonsumsi tetapi tidak matang baik melalui direbus atau digoreng, maka dikhawatirkan masih terdapat bakteri pada hewan tersebut, sehingga daging harus diolah hingga benar-benar matang. Pada masa kini, pemanfaatan kadal untuk obat alergi gatal sudah jarang dilakukan, karena masyarakat Sumber lebih sering mengonsumsi obat-obat kimia yang dijual di apotek. Selain obat kimia, masyarakat Sumber lebih memanfaatkan flora atau tumbuhan herbal untuk mengobati alergi gatal.

Berdasarkan wawancara terhadap narasumber 2, menyatakan bahwa setelah memakan daging kadal efek yang dirasakan di dalam tubuh adalah rasa hangat pada seluruh tubuh. Setelah itu, beberapa hari kemudian, rasa gatalgatal yang dialami menjadi reda dan hilang. Rasa hangat tersebut merupakan respon tubuh bahwa kandungan yang terdapat pada daging kadal bereaksi dengan baik. Menurut Ehling dkk. (2015), rasa gatal yang timbul pada kulit dikarenakan kulit memiliki suatu reseptor yang disebut dengan pruriceptors atau ujung saraf yang dapat mendeteksi gatal tersebut 
terstimulasi. Hal tersebut merupakan bagian dari respon kekebalan tubuh atau imunitas tubuh untuk mengeluarkan suatu zat yang disebut dengan histamin yang dapat mengakibatkan gatal. Histamin merupakan suatu mediator inflamasi yang kuat, umumnya berkaitan dengan reaksi alergi yang dapat mendorong perubahan pembuluh darah dan jaringan serta memiliki aktivitas chemoattactant yang tinggi. (Ehling dkk., 2015)

Kadal dapat dimanfaatkan sebagai obat tradisional untuk meringankan gatal-gatal karena kadal memiliki suatu kandungan zat antimikroba. Menurut Santos dkk. (2013), kadal dapat dimanfaatkan dalam pengobatan tradisional, karena kadal memiliki kandungan yang dapat melawan bakteri dan juga jamur patogen. Hal tersebut menunjukkan bahwa kadal digunakan sebagai agen antimikroba yang potensial. Sehingga kadal dapat digunakan sebagai obat tradisional dalam mengobati penyakit bisul, dermatitis, dan penyakit kulit lainnya serta dapat mengobati penyakit kelamin.

Menurut Hamdani dkk. (2013), daging kadal dapat konsumsi secara langsung dengan digoreng terlebih dahulu, maupun dibuat menjadi minyak kadal. Manfaatnya yaitu untuk mengobati jenis penyakit kulit, seperti eksim, gatal-gatal, dan juga alergi. Menurut Juniarmi dkk. (2014), secara tradisional kadal telah dimanfaatkan sebagai obat dalam penyembuhan penyakit kulit oleh manusia. Selain itu, kadal dapat digunakan sebagai pengganti dari tepung ikan, karena tepung kadal memiliki suatu kandungan protein kasar di dalam bahan kering sebesar $60,72 \%$.
Islam.

Hukum Memakan Kadal dalam

Menurut Imam Al-Bukhari di dalam sakah satu kitabnya yaitu Kitab Khabarul Ahad, bab Khobarul Mar'ah Waahidah yang artinya bahwa "Abdullah bin Umar RA. berkata: "Orang-orang dari kalangan sahabat Nabi SAW, yang mana diantara mereka terdapat Sa'ad memakan daging. Kemudian, salah seorang istri Nabi memanggil mereka, seraya berkata. 'Itu adalah daging dhab'. Lalu, mereka pun berhenti makan. Maka Rasulullah SAW bersabda "Makanlah, karena daging tersebut halal atau beliau bersabda "tidak mengapa dimakan, akan tetapi daging hewan tersebut bukanlah makananku." Berdasarkan hadits tersebut, dhab adalah suatu jenis kadal herbivora yang memiliki kulit cerah dan tidak memangsa hewan lain atau buas. Jadi, dalam agama Islam daging kadal dibolehkan atau diizinkan untuk dikonsumsi dengan syarat kadal itu termasuk ke dalam kadal jenis dhab dan bukan jenis biawak yang buas.

\section{KESIMPULAN}

Berdasarkan hasil penelitian yang telah dilakukan, maka dapat disimpulkan bahwa kadal (Eutropis multifasciata) dapat dimanfaatkan dalam bidang farmasi sebagai obat tradisional terhadap alergi gatal, eksim, bisul dan penyakit kulit lainnya. Karena kadal memiliki kandungan antimikroba yang dapat melawan bakteri dan juga jamur patogen. Berdasarkan hadits Bukhari, memakan kadal diperbolehkan dengan syarat kadal termasuk termasuk jenis dhab (Kadal herbivora) dan bukan biawak yang buas. 


\section{DAFTAR PUSTAKA}

Anderson, E.N., Pearsall, D., Hunn, \& Tuener, N. (2011). Etnobiology. John Wiley \& Sons, Inc: Canada.

Buller, J. L. (2012). Best practices in faculty evaluation: A practical guide for academic leaders. John Wiley \& Sons.

Ehling, S., Robach, K., Dunston, S.M., Stark, H., \& Baumer, W. (2016). Allergic Inflammation is Augmented via Histamine $\mathrm{H} 4$ Receptor Activation: The Role of Natural Killer Cell in Vitro and in Vivo. Journal of Dermatological Science. 83(2): 106-115.

Eprilurahman, R., Hadisusanta, S., Yudha, D.S., Ramadani, T.R.S., Pranoto, F.S., \& Muhtianda, I.A. (2018). Kekayaan Fauna, Gianyar Bali. Yogyakarta: Gadjah Mada University Press.

Hamdani, R., Tjong, D.H., \& Herwina, H. (2013). Potensi Herpetofauna dalam Pengobatan Tradisional di Sumatera Barat. Jurnal Biologi Universitas Andalas. 2(2): 110117.

Hamny, Mulyani, S., Masyith, D., Wahyuni, S., \& Jalaluddin, M. (2015). Morfologi Anatomi dan Histologi Usus Biawak Air (Varanus salvator). Jurnal Veteriner. 16(2): 152-158.

Juniarmi, R., Nurdin, J., \& Zakaria, I.J. (2014). Kepaatan Populasi dan Distribusi Kadal (Eutropis multifasciata Kuhl.) di PulauPulau Kecil Kota Padang. Jurnal Biologi Universitas Andalas. 3(1): 51-56.

Krisyanto, R.D., Ardian, H., \& Anwari, M.S. (2019). Kajian Etnozoologi untuk Pengobatan Suku Dayak Sebaruk di Desa Setunggil Kecamatan Silat Hilir Kabupaten
Kapuas Hulu. Jurnal Hutan Lestari. 7(3): 1287-1289.

Lesmana, H., Alfianur, Utami, P.A., Retnowati, Y., \& Darni. (2018). Pengobatan Tradisional Masyarakat Tidung Kota Tarakan: Study Kualitatif Kearifan Lokal Bidang Kesehatan. Jurnal Ilmiah IlmuIlmu Kesehatan. 16(1): 31-40.

Rosadi, A.B., Slamet, A., \& Madang, K. (2017). Identifikasi Jenis-Jenis Reptilia (Subordo Suria) di Taman Wisata Alam Bukit Kaba Kabupaten Rejang Lebong Provinsi Bengkulu dan Kontribusinya dalam Pembelajaran Biologi SMA. Jurnal Pembelajaran Biologi. 4(1): 88-93.

Rousdy, D.W., \& Linda. (2018). Hematologi Perbandingan Hewan Vertebrata: Lele (Clarias batrachus), Katak (Rana sp.), Kadal (Eutropus multifasciata), Merpati (Columba livia) dan Mencit (Mus musculus). Jurnal Universitas PGRI Semarang. 7(1): 1-13.

Santos, I.J.M., dkk. (2013). Antimicrobial Activity of Natural Product from the Skins the Semiarid Living Lizards Ameiva ameiva. Journal of Arid Environments. 76: 138-141.

Walia, B., \& Gusnita, W. (2020). Kualitas Rendang Daging dengan Alat Pemanas Yang Berbeda. Jurnal Pendidikan Tata Boga dan Teknologi. 1(3): 136-141.

Yuni, L.P.E.K., Jones, S.M., \& Wapsra, E. (2018). Thermal Biology of the Spotted Snow Skink, Niveosincus ocellatus, along an Altitudinal Gradient. Australia Journal of Zoology. 66: 235-246. 